\title{
Biological evaluation of 2,3-dioxoindolin- $N$-phenylacetamide derivatives as potent CDC25B and PTP1B phosphatase inhibitors
}

\author{
Qing-Hao Jin', Wen-Bo Chen ${ }^{\circledR 1,2}$, Ya-Nan Xia ${ }^{3}$, Bing-Yu Liu ${ }^{3}$, Li-Ping Guan ${ }^{3 *}$ \\ ${ }^{1}$ Zhejiang Ocean University, DongHai Science and Technology College, Zhejiang, Zhoushan, P.R. China, ${ }^{2}$ Hailisheng \\ Pharmaceutical Co Lid, Zhejiang, Zhoushan, P. R. China, ${ }^{3}$ Food and Pharmacy College, Zhejiang Ocean University, Zhejiang, \\ Zhoushan, P. R. China
}

\begin{abstract}
A series of 2,3-dioxoindolin- $N$-phenylacetamide derivatives was evaluated for inhibitory activity against CDC25B and PTP1B enzymes. Most of the derivatives showed inhibitory activity against CDC25B $\left(\mathrm{IC}_{50}=3.2-23.2 \mu \mathrm{g} / \mathrm{mL}\right)$ and PTP1B $\left(\mathrm{IC}_{50}=2.9-21.4 \mu \mathrm{g} / \mathrm{mL}\right)$. Compound $\mathbf{2 h}$ showed the most inhibitory activity in vitro with $\mathrm{IC}_{50}$ values of 3.2 and $2.9 \mu \mathrm{g} / \mathrm{mL}$ against $\mathrm{CDC} 25 \mathrm{~B}$ and $\mathrm{PTP} 1 \mathrm{~B}$, respectively, compared with the reference drugs $\mathrm{Na}_{3} \mathrm{VO}_{4}\left(\mathrm{IC}_{50}=2.7 \mu \mathrm{g} / \mathrm{mL}\right)$ and oleanolic acid $\left(\mathrm{IC}_{50}=2.3 \mu \mathrm{g} / \mathrm{mL}\right)$. The results of selectivity experiments showed that the 2,3-dioxoindolin- $N$-phenylacetamide derivatives were selective inhibitors against CDC25B and PTP1B. Enzyme kinetic experiments demonstrated that compound $\mathbf{2 h}$ was a specific inhibitor with the typical characteristics of a mixed inhibitor. In cytotoxic activity assays compound $\mathbf{2 h}$ had potent activity against A549, HeLa, and HCT116 cell lines. In addition, compound $\mathbf{2 h}$ showed potent tumor inhibitory activity in a colo2 05 xenograft model in vivo.
\end{abstract}

Keywords: Dioxoindolin- $N$-phenylacetamide. CDC25B. PTP1B. Phosphatase inhibitors. Enzyme kinetics.

\section{INTRODUCTION}

Cell division cycle 25 phosphatase (CDC25) enzymes are potential targets for the development of new cancer therapeutic agents (Contour-Galcera et al., 2007). CDC25, a subfamily of dual-specificity protein tyrosine phosphatases, which includes CDC25A, B, and $\mathrm{C}$ homologues, plays a pivotal role in the regulation of the cell cycle (Rudolph, 2007). Current drug discovery efforts are being directed toward identifying novel CDC25 inhibitors that work in vitro, and compounds that may be active against human tumors in vivo have been reported. In particular, CDC25B isoforms are known to be overexpressed in primary tissue samples from various human cancers, and this overexpression is strongly associated with tumor aggressiveness and poor prognosis (Lavecchia, Di Giovanni, Novellino, 2011; Lavecchia et al., 2008).

Protein tyrosine phosphatase 1B (PTP1B) is the most characterized of all the tyrosine phosphatases and acts as a critical negative and positive regulator of numerous

*Corresponding: L.-P. Guan. Food and Pharmacy College, Zhejiang Ocean University, 316022 - Zhoushan, Zhejiang, P. R. China. E-mail: glp730@163.com signaling cascades (Feldhammer et al., 2013; Low, Chai, Yao, 2014). PTP1B is expressed in multiple tissues including the liver, adipose tissue, skeletal muscle, and the brain. PTP1B is involved in multiple signal transduction pathways (Julien et al., 2007). PTP1B is also a key player in cancer regulation serving as both a tumor suppressor and tumor promoter depending on the cellular context.

Isatin (2,3-dioxoindolin) is an endogenous compound in humans that possesses a wide range of biological activities. In recent years, various isatin derivatives have been identified that act as antibacterial, anticonvulsant, antifungal, antitubercular, antiviral, and anticancer agents (Pandeya et al., 2005; Pandeya, Raja, 2002). It is well-documented that apoptosis, or programmed cell death, is the key mechanism by which chemo-therapeutic agents exert their cytotoxicity (Tripathi, Krishnamurthy, Ayyannan, 2016; Modi et al., 2011). Recently, several isatin derivatives have been shown to display appreciable cytotoxicity (Figure 1). For example, Popp (Sukhramani, Desai, Suthar, 2011) synthesized 3-o-nitrophenyl hydrazones of isatin by condensation of isatin with $o$-nitrophenyl hydrazine. These compounds were found to be active intramuscularly against Walker carcinoma-256 and inactive against L-1210 lymphoid 
leukemia in animal models. A novel series of 5-(2-oxo3-indolinyl) thiazolidine-2,4-diones having substitutions prepared using various Mannich bases at positions 1 and 3 of the isatin and thiazolidine rings, respectively, has been synthesized by Eshba and Salama (Eshbha, Salama, 1985). Five compounds were evaluated for antileukemic activity against p388 lymphocytic leukemia in mice. The di-Mannich base with a dimethyl amino component exhibited the highest activity of the tested compounds. The introduction of bromine into the aromatic moiety of the isatin ring at position 5 increased the activity compared with the parent molecule to a small extent. Teitz et al. (1993) studied the selective repression of the V-alb coded protein $(\mathrm{P} 120)$ on the oncogene product associated with tyrosine kinase activity using $N$-methylisatin-4',4'-diethyl thio-semicarbazone and $N$-allylisatin-4',4'-diallyl thiosemicarbazone. These compounds selectively suppressed the $\mathrm{V}$-alb oncogene, as well as the Moloney murine leukemia virus. Broadbent, Thomas and Broadbent (1998) reviewed the chemistry and pharmacology of indole-3carbinol and 3-methoxymethylindole; these compounds showed antimutagenic and anticarcinogenic properties against a variety of classes of carcinogens and acted as anticancer agents against certain common neoplasms.

In our previous work, we found that compound I [2-(6-bromo-2,3-dioxoindolin-1-yl)- $N$ - (2-bromophenyl) acetamide] displayed inhibitory activity against CDC25B and PTP1B $\left(\mathrm{IC}_{50}=3.87\right.$ and $2.98 \mu \mathrm{mol} / \mathrm{L}$, respectively), and also showed cytotoxic activity against three cancer cell lines (HeLa, A549, and HCT116). In addition, compound I displayed potent tumor inhibitory activity in a colo205 xenograft model in vivo (Zhao et al., 2015a). To further investigate the anticancer effects of CDC25B and PTP1B inhibitors, we synthesized a series of 2,3-dioxoindolin- $N$-phenylacetamide derivatives and investigated the structure-activity relationships. The synthetic pathway for compounds $\mathbf{2 a - 2 o}$ is illustrated in Scheme 1. Compound $\mathbf{2 h}$ was selected for a kinetics study and selectivity analysis to determine whether these compounds are suitable for further development. The pharmacological results showed that all of the tested compounds significantly inhibited CDC25B and $\mathrm{PTP} 1 \mathrm{~B}$ in vitro. The mechanism of this inhibition was also studied.

\section{MATERIAL AND METHODS}

\section{Reagents}

2,3-Dioxoindolin-1-yl- $N$-phenylacetamides (2a-2o) were synthesized as described previously (Xie et al., 2014 a). All compounds were confirmed from the IR spectra (FT-IR1730, Bruker, Switzerland), ${ }^{1} \mathrm{H}-\mathrm{NMR}$ and ${ }^{13} \mathrm{C}-\mathrm{NMR}$ spectra (AV-300, Bruker, Switzerland), mass spectra (HP1100LC/MS, Agilent Technologies, USA), and elemental analyses (CHN) (Perkin Elmer 204Q CHN). 3-O-Methylfluorescein phosphate (OMFP), 3-(4,5-dimethylthiazol-2-yl)-2,5-diphenyltetrazoliom bromide (MTT), and A549, HeLa, and HCT116 cells were purchased from Sigma Aldrich (St Louis, MO, USA). All<smiles>O=C(CN1C(=O)C(=O)c2cc(Br)ccc21)Nc1ccccc1Br</smiles>

I

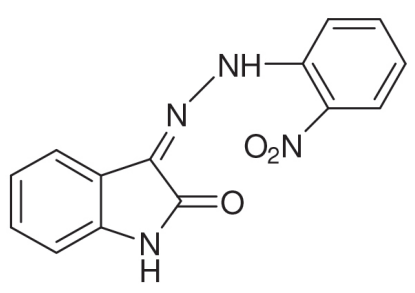<smiles>O=C1C(=O)C(C(=O)Nc2ccccc2[N+](=O)[O-])c2c(Br)cc(Br)cc21</smiles><smiles>CNCN1C(=O)SC(N=C2C(=O)N(CNC)c3ccc(Br)cc32)C1=O</smiles><smiles>O=C1C(=O)C(C(=O)Nc2cccc([N+](=O)[O-])c2)c2ccccc21</smiles>

FIGURE 1 - Structures of isatin derivatives reported to be CDC25B and PTP1B inhibitors and I. 


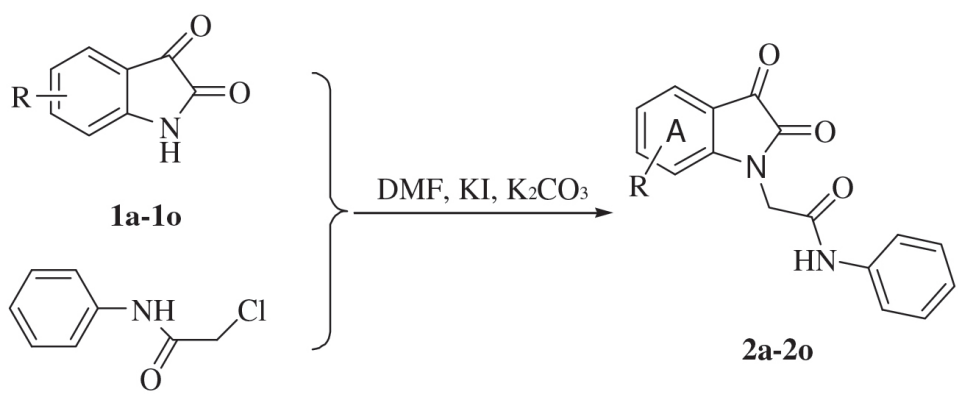

$$
\begin{array}{lllll}
\mathrm{R}: & & & & \\
\mathbf{2} \mathbf{a}=\mathrm{H} & \mathbf{2} \mathbf{b}=4-\mathrm{CH}_{3} & \mathbf{2} \mathbf{c}=5-\mathrm{CH}_{3} & \mathbf{2 d}=6-\mathrm{CH}_{3} & \mathbf{2 e}=4-\mathrm{F} \\
\mathbf{2 f}=5-\mathrm{F} & \mathbf{2} \mathbf{g}=6-\mathrm{F} & \mathbf{2 h}=4-\mathrm{Cl} & \mathbf{2 i}=5-\mathrm{Cl} & \mathbf{2} \mathbf{j}=6-\mathrm{Cl} \\
\mathbf{2 k}=4-\mathrm{Br} & \mathbf{2 l}=5-\mathrm{Br} & \mathbf{2 m}=6-\mathrm{Br} & \mathbf{2 n}=4,6-\mathrm{Br}_{2} & \mathbf{2 0}=6-\mathrm{NO}_{2}
\end{array}
$$

SCHEME 1 - The synthetic pathway for compounds $\mathbf{2 a - 2 0}$

other reagents and solvents used in the experiments were of analytical grade.

\section{Biological activity assay for CDC25B}

The enzymatic activity of the CDC $25 \mathrm{~B}$ catalytic domain was determined by monitoring the dephosphorylation of OMFP. The dephosphorylation of OMFP generates3-O-Methylfluorescein (OMF), which was detected at $485 \mathrm{~nm}$ excitation $/ 535 \mathrm{~nm}$ emission wavelengths. A typical $100-\mu \mathrm{L}$ assay mixture contained Tris- $\mathrm{HCl}(50 \mathrm{mmol} / \mathrm{L}), \mathrm{NaCl}(50 \mathrm{mmol} / \mathrm{L})$, OMFP $(5 \mu \mathrm{mol} / \mathrm{L})$, recombinant CDC25B $(20 \mathrm{nmol} / \mathrm{L})$, $1 \%$ glycerin, and DTT $(1 \mathrm{mmol} / \mathrm{L})$, in the presence or absence, of $2 \mu \mathrm{L}$ of compounds $\mathbf{2 a - 2 o}$ in dimethyl sulfoxide (DMSO); $\mathrm{pH}$ 8.0. The activity was continuously monitored and the initial rate of the dephosphorylation was determined using the early linear region of the enzymatic reaction kinetic curve. Continuous kinetic monitoring was performed in clear 96-well plates (Corning, Lowell, MA) (Cossy et al., 2006; Zhao et al., 2015b).

\section{Biological activity assays for PTP1B}

The enzymatic assays for PTP1B were performed as described elsewhere (Cossy et al., 2006). Briefly, the enzymatic activity of the PTP1B catalytic domain was determined at $30{ }^{\circ} \mathrm{C}$ by monitoring the hydrolysis of $p$-nitrophenyl phosphate ( $p$ NPP). Dephosphorylation of $p$ NPP generates the product $p$-nitrophenyl ( $p$ NP), which was monitored at an absorbance of $405 \mathrm{~nm}$ using an EnVision multilabel plate reader (PerkinElmer Life Sciences, Boston, MA, USA). Assays were performed in a total volume of $100 \mu \mathrm{L}$ containing $50 \mathrm{mM}$
3-[N-morpholino]propanesulfonicacid (MOPs), $2 \mathrm{mM}$ $p \mathrm{NPP}$, and $20 \mathrm{nM}$ recombinant PTP1B; $\mathrm{pH} 6.5$, as well as varying concentrations of compounds $\mathbf{2 a}-\mathbf{2 o}$.

\section{Enzyme kinetic analysis of compound $2 \mathrm{~h}$}

Compound $\mathbf{2 h}$ was tested in enzyme kinetic assays according to previous studies (McGovern et al., 2003; Sun et al., 2013a). The assays were performed in a total volume of $100 \mu \mathrm{L}$ including $30 \mathrm{nM}$ PTP $1 \mathrm{~B}, 50 \mathrm{mM}$ MOPS; $\mathrm{pH} 6.5$, and $p$ NPP in twofold dilutions from 80 $\mathrm{mM}$, and different concentrations of $\mathbf{2} \mathbf{h}$. In the presence of a competitive inhibitor, the Michaelis-Menten equation is described by $1 / \mathrm{v}=\left(\mathrm{K}_{\mathrm{m}} /\left[\mathrm{V}_{\max }[\mathrm{S}]\right]\right)\left(1+[\mathrm{I}] / \mathrm{K}_{\mathrm{i}}\right)+1 / \mathrm{V}_{\max }$, where $v=$ the initial rate, $\mathrm{V}_{\max }=$ the maximum rate, and $[\mathrm{S}]=$ the substrate concentration. The $\mathrm{K}_{\mathrm{i}}$ value was determined from a linear replot of the apparent $\mathrm{K}_{\mathrm{m}} / \mathrm{V}_{\max }$ slope from the primary reciprocal plot versus inhibitor concentration [I] according to the equation $\mathrm{K}_{\mathrm{m}} / \mathrm{V}_{\max }=1+[\mathrm{I}] / \mathrm{K}_{\mathrm{i}}$.

\section{Cell cultures}

A549, HeLa, and HCT116 cells were kept at logarithmic growth in HG-DMEM, McCoy's 5A, and F12 mediums, respectively, at $5 \% \mathrm{CO}_{2}$ and $37^{\circ} \mathrm{C}$ supplemented with $10 \% \mathrm{FBS}$ and 100 units/mL each of penicillin $\mathrm{G}$ and streptomycin.

\section{Cytotoxicity assays for compound $\mathbf{2 h}$}

Cytotoxicity assays were performed on human colon cancer (HCT116) and cervical carcinoma cell lines. Cells (6000-10000) in $100 \mu \mathrm{L}$ culture medium per well were seeded onto a 96-well microtest plate (Falcon, CA, USA). Cells were treated in triplicate; a gradient concentration of 
tested compounds was added and the plate was incubated at $37^{\circ} \mathrm{C}$ for $72 \mathrm{~h}$. For the three cell lines, a MTT assay was performed to measure cytotoxic effects. The $\mathrm{IC}_{50}$ values of the tested compounds for the tumor cells were determined from the dose-response curves.

\section{Antitumor effect of compound $2 \mathrm{~h}$ in vivo}

The antitumor effect of compound $\mathbf{2 h}$ was evaluated in vivo and compared with the reference drug IRT. BALB/C nude male mice (weight 18-20 g) were obtained from the Laboratory of Animal Research, College of Pharmacy, Zhejiang Academy of Medical Sciences. Colo205 cancercell suspensions were subcutaneously implanted into the right axilla region of the mice. Treatment began when the implanted tumor had reached a volume of $100-300 \mathrm{~mm}^{3}$ (after 17 days). The animals were randomized into treatment and control groups (10 animals per group), and BALB/C nude male mice administered by gavage once daily for 5 consecutive days from day 17 after implantation of the cells. Tumor volumes were monitored by caliper measurement of the length and width and calculated using the formula: $\mathrm{TV}=1 / 2 \times \mathrm{a} \times \mathrm{b}^{2}$, where $\mathrm{a}$ is the tumor length and $b$ is the width. Tumor volumes and body weights were monitored every 4 days over the course of the treatments. Mice were sacrificed on day 35 after implantation of cells, and the tumors were removed and recorded for analysis. All procedures used were in accordance with the guide for the Care and Use of Laboratory Animals as adopted by the NIH, and the lab received ethical approval from the National Science and Technology Commission of China for the present study.

\section{RESULTS AND DISCUSSION}

\section{Effects of derivatives 2a-2o on CDC25B and PTP1B in vitro}

Human CDC25B is a central target and regulator of the $\mathrm{G}_{2} / \mathrm{M}$ checkpoint mechanisms activated in response to DNA injury. The effect of these enzymes and their expression is finely regulated by multiple mechanisms, including interactions with regulatory partners, posttranslational modifications, control of intracellular localization, and cell cycle-regulated degradation. CDC25B has been identified as a potential target for anticancer therapeutics (Zarling et al., 2014; Aressy, Ducommun, 2008; Mak et al., 2012).

The inhibitory effect of compounds $\mathbf{2 a - 2 o}$ against CDC25B was tested using OMFP as a substrate. $\mathrm{Na}_{3} \mathrm{VO}_{4}$, a known CDC25B inhibitor, was used as a positive control, and the results are summarized in Table I. The tested compounds dose-dependently inhibited CDC25B with $\mathrm{IC}_{50}$ values ranging from 3.2 to $23.2 \mu \mathrm{g} / \mathrm{mL}$. Among them, compound $\mathbf{2 h}$ showed the most potent inhibitory activity for $\mathrm{CDC} 25 \mathrm{~B}\left(\mathrm{IC}_{50}=3.2 \mu \mathrm{g} / \mathrm{mL}\right)$, and the inhibitory activity was close to that of the positive control $\mathrm{Na}_{3} \mathrm{VO}_{4}$ $\left(\mathrm{IC}_{50}=2.7 \mu \mathrm{g} / \mathrm{mL}\right)$ (Table 1).

TABLE I - Inhibitory activity of compounds $\mathbf{2 a - 2 o}$ against CDC25B and PTP1B

\begin{tabular}{lcc}
\hline \multirow{2}{*}{ Compounds } & \multicolumn{2}{c}{$\mathbf{I C}_{50}(\boldsymbol{\mu g} / \mathbf{m L})$} \\
\cline { 2 - 3 } $\mathbf{2 a}$ & $\mathbf{C D C 2 5 B}$ & $\mathbf{P T P 1 B}$ \\
$\mathbf{2 b}$ & $16.7 \pm 1.28$ & $14.5 \pm 2.12$ \\
$\mathbf{2 c}$ & $15.2 \pm 1.61$ & $11.3 \pm 1.54$ \\
$\mathbf{2 d}$ & $21.5 \pm 1.95$ & $19.5 \pm 2.70$ \\
$\mathbf{2 e}$ & $20.1 \pm 2.74$ & $21.4 \pm 2.47$ \\
$\mathbf{2 f}$ & $10.3 \pm 3.03$ & $11.1 \pm 3.44$ \\
$\mathbf{2 g}$ & $16.2 \pm 3.92$ & $15.1 \pm 3.84$ \\
$\mathbf{2 h}$ & $13.2 \pm 2.02$ & $12.5 \pm 1.96$ \\
$\mathbf{2 i}$ & $3.2 \pm 0.98$ & $2.9 \pm 0.52$ \\
$\mathbf{2 j}$ & $14.7 \pm 3.53$ & $15.3 \pm 1.36$ \\
$\mathbf{2 k}$ & $12.4 \pm 2.37$ & $13.9 \pm 4.35$ \\
$\mathbf{2 l}$ & $4.7 \pm 1.13$ & $4.5 \pm 1.88$ \\
$\mathbf{2 m}$ & $11.6 \pm 1.89$ & $12.7 \pm 3.49$ \\
$\mathbf{2 n}$ & $15.8 \pm 3.76$ & $16.3 \pm 2.77$ \\
$\mathbf{2 0}$ & $5.0 \pm 1.80$ & $6.4 \pm 1.25$ \\
$\mathrm{Na}_{3} \mathrm{VO}_{4}$ & $23.2 \pm 2.13$ & $20.2 \pm 2.43$ \\
Oleanolic acid $^{\mathbf{d}}$ & $2.7 \pm 1.16$ & - \\
\hline
\end{tabular}

The structure activity relationships of compounds 2a-2o were analyzed against CDC25B. Compounds $\mathbf{2 b - 2 0}$ contained electron-withdrawing groups and electron-donating groups on the A ring. Three compounds 2b-2d with electron-donor containing were designed and synthesized, containing $o-\mathrm{CH}_{3}, m-\mathrm{CH}_{3}$ and $p-\mathrm{CH}_{3}$. Compound $\mathbf{2 b}\left(o-\mathrm{CH}_{3}\right)$ displayed the most potent inhibitory activity for $\mathrm{CDC} 25 \mathrm{~B}\left(\mathrm{IC}_{50}=15.2 \mu \mathrm{g} / \mathrm{mL}\right)$. Compounds $2 \mathbf{c}\left(m-\mathrm{CH}_{3}\right)$ and $\mathbf{2 d}\left(p-\mathrm{CH}_{3}\right)$ exhibited slight activity inhibition effects with $\mathrm{IC}_{50}>20 \mu \mathrm{g} / \mathrm{mL}$, with an activity order of was $o-\mathrm{CH}_{3}>p-\mathrm{CH}_{3}>m-\mathrm{CH}_{3}$. Compound 2a non-substituent (-H) on the A ring displayed good inhibition activity for $\mathrm{CDC} 25 \mathrm{~B}\left(\mathrm{IC}_{50}=16.7 \mu \mathrm{g} / \mathrm{mL}\right)$. Except $20\left(\mathrm{IC}_{50}=23.2 \mu \mathrm{g} / \mathrm{mL}\right)$, The halogen substituted compounds $\mathbf{2 e - 2 n}$ with electron-withdrawing groups seemed to show better activity than compounds containing electron-donating groups on the whole level. These results 
indicated that electron-withdrawing groups facilitated CDC25B inhibition. We also found that the position of the substituent on the A ring significantly influenced CDC25B inhibition effects, with an activity order of was $o-\mathrm{F}>p-\mathrm{F}>m-\mathrm{F}$ for fluorinated compounds; $o-\mathrm{Cl}>p-\mathrm{Cl}>$ $m-\mathrm{Cl}$ for chlorinated compounds; $o-\mathrm{Br}>2,4-\mathrm{Br}_{2}>m-\mathrm{Br}>$ $p$-Br for bromined compounds. Among them, compounds $\mathbf{2 h}(o-\mathrm{Cl}), \mathbf{2} \mathbf{k}(o-\mathrm{Br})$ and $\mathbf{2 n}\left(2,4-\mathrm{Br}_{2}\right)$ showed better inhibition activity against $\mathrm{CDC} 25 \mathrm{~B}$ with $\mathrm{IC}_{50}$ values of 3.2 , 4.7 and $5.0 \mu \mathrm{g} / \mathrm{mL}$, respectively. The electron-withdrawing group compound $\mathbf{2 n}\left(p-\mathrm{NO}_{2}\right)$ showed slightly inhibitory activity $\left(\mathrm{IC}_{50}=23.2 \mu \mathrm{g} / \mathrm{mL}\right)$.

PTP1B is a ubiquitously expressed phosphatase that contains a catalytic domain and a C-terminal domain of mainly hydrophobic residues that are involved in targeting the enzyme to the cytoplasmic face of the endoplasmic reticulum. A range of biochemical, cellular and knockout mouse studies have revealed that PTP1B functions as a negative regulator of both the insulin and leptin receptor signaling pathways. Moreover, ablation of PTP1B confers resistance to obesity induced by a high-fat diet. PTP1B is also as key player in cancer serving as both tumor promoter and tumor suppressor depending on the cellular context. (Shi et al., 2008; Barr, 2010; Feldhammer et al., 2013; Malla, Kumar, Kumar, 2013; Reddy et al., 2014).

The inhibitory activity of the synthesized compounds (2a-2o) against PTP1B was measured using $p$ NPP as a substrate. Oleanolic acid, a known PTP1B inhibitor, was used as a positive control. The results are shown in Table I. All of the tested compounds showed inhibitory effects against PTP1B with $\mathrm{IC}_{50}$ values ranging from 2.9 to $21.4 \mu \mathrm{g} / \mathrm{mL}$. Compound $\mathbf{2 h}$ exhibited the most potent inhibitory activity for PTP1B ( $\left.\mathrm{IC}_{50}=2.9 \mu \mathrm{g} / \mathrm{mL}\right)$, and the inhibitory activity was similar to the positive control oleanolic acid $\left(\mathrm{IC}_{50}=2.3 \mu \mathrm{g} / \mathrm{mL}\right)$. In general, the halogensubstituted compounds $\mathbf{2 e - 2 n}$ with electron-withdrawing groups displayed better activity than compounds containing electron-donating groups. The order of potency was $o-\mathrm{F}>p-\mathrm{F}>m-\mathrm{F}$ for fluorinated compounds; $o-\mathrm{Cl}$ $>p-\mathrm{Cl}>m-\mathrm{Cl}$ for chlorinated compounds; and $o-\mathrm{Br}>$ $2,4-\mathrm{Br}_{2}>m-\mathrm{Br}>p$ - $\mathrm{Br}$ for brominated compounds. Compound 20 with an electron-withdrawing group $\left(p-\mathrm{NO}_{2}\right)$ also exhibited potent inhibitory activity against PTP1B $\left(\mathrm{IC}_{50}=20.2 \mu \mathrm{g} / \mathrm{mL}\right)$. For the three compounds $\mathbf{2 b}-\mathbf{d}$ with electron-donating groups, the order of activity was $o-\mathrm{CH}_{3}>m-\mathrm{CH}_{3}>p-\mathrm{CH}_{3}$. The $\mathrm{IC}_{50}$ value for compound 2b was $11.3 \mu \mathrm{g} / \mathrm{mL}$. Compound 2a, non-substituted (-H) on the A ring, displayed good inhibitory activity for PTP1B $\left(\mathrm{IC}_{50}=14.5 \mu \mathrm{g} / \mathrm{mL}\right)$. CDC25B and PTP1B are potential targets for the development of new cancer therapeutic agents. Current drug discovery efforts are directed toward identifying novel CDC25B and PTP1B inhibitors, and derivatives that may be active against human tumors have been reported (Li et al., 2014; Xie et al., 2014b). In the present study, all of the tested compounds significantly inhibited CDC25B and PTP1B, which indicates that these compounds may possess anticancer activity.

\section{Enzyme kinetic assays of compound $2 \mathrm{~h}$}

A kinetic study was used to clarify the inhibitory mechanism of compound $\mathbf{2 h}$. The assays were executed according to procedures described previously (Shi et al., 2008; McGovern et al., 2003; Sun et al., 2012b). As illustrated in Figure 2A, compound $\mathbf{2 h}$ showed time-independent inhibition of PTP1B and the results indicated that compound $\mathbf{2 h}$ was a fast-binding inhibitor of PTP1B. The time-independent behavior of compound $\mathbf{2 h}$ was also able to be eliminated with regard to PTP1B, so compound $\mathbf{2 h}$ is a nonspecific inhibitor, because nonspecific inhibitors always exhibit time-dependent behavior and a steep inhibition curve. In further analysis of the mechanism of inhibition of PTP1B; compound $\mathbf{2 h}$ displayed characteristics typical of a competitive inhibitor, with increased $K_{m}$ values and reduced $V_{\max }$ values with increases in concentration (Figure 2B). Moreover, because all the plots for different concentrations of compound $\mathbf{2 h}$ intersect on the y-axis, the Lineweaver-Burk plot suggested that compound $\mathbf{2 h}$ is a competitive inhibitor for PTP1B (Figure 2C). The results indicated that compound $\mathbf{2 h}$ binds to the catalytic pocket of PTP1B and competes with the physiological substrate. The $\mathrm{K}_{\mathrm{i}}$ value, calculated from Figure 2D, was $0.502 \mu \mathrm{M}$.

\section{Compound $2 \mathrm{~h}$ inhibited cell proliferation}

A549, HCT116, and HeLa cells were used to investigate the effect of compound $\mathbf{2 h}$ on the proliferation of cancer cells. Cells were seeded at 2000 cells per well in a 96-well microplate. After $24 \mathrm{~h}$, cells were treated with the indicated concentrations of compound $\mathbf{2 h}$ for 72 $\mathrm{h}$, using $1 \%$ DMSO as a negative control. The viability of cells was evaluated using the MTT method. As shown in Table II, compound $\mathbf{2 h}$ markedly inhibited the proliferation of A549 cells $\left(\mathrm{IC}_{50}=2.86 \pm 0.19 \mu \mathrm{mol} / \mathrm{L}\right)$, HCT116 cells $\left(\mathrm{IC}_{50}=3.59 \pm 0.27 \mu \mathrm{mol} / \mathrm{L}\right)$, and HeLa cells $\left(\mathrm{IC}_{50}=2.78 \pm 0.11 \mu \mathrm{mol} / \mathrm{L}\right)$.

\section{Antitumor activity for compound $2 \mathrm{~h}$ in vivo}

On the basis of the favourable data for compound $\mathbf{2 h}$ in vitro, its antitumor activity in the colo205 (colon 


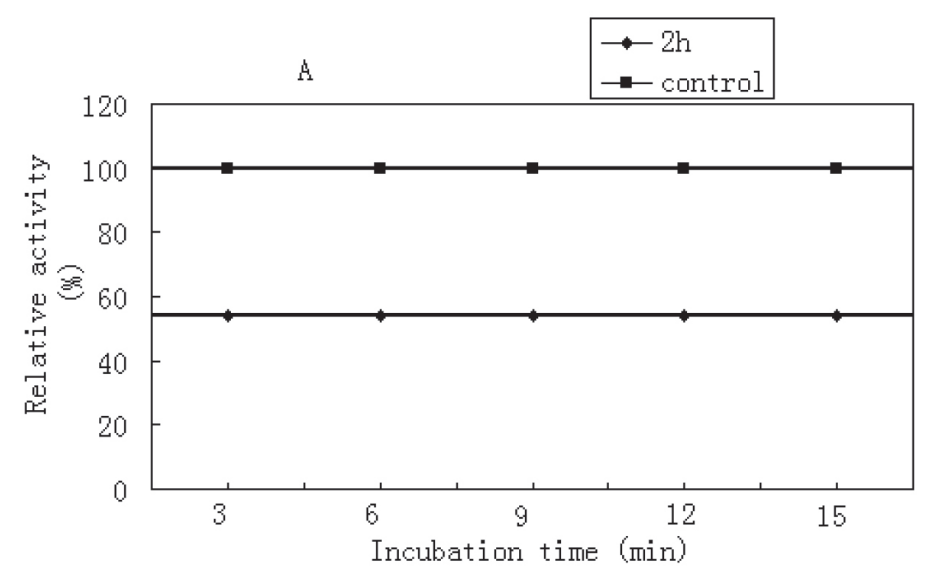

B
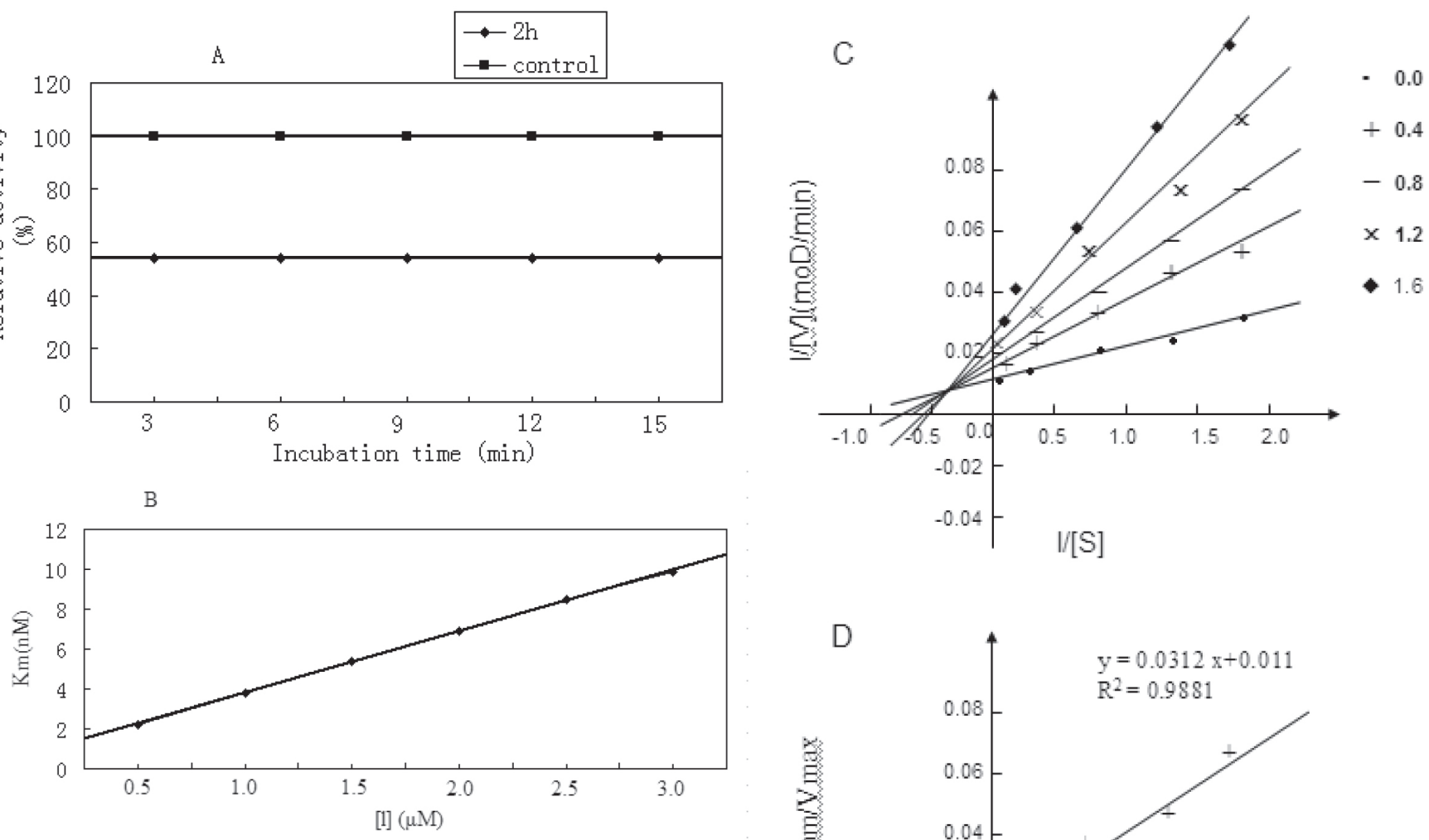

B
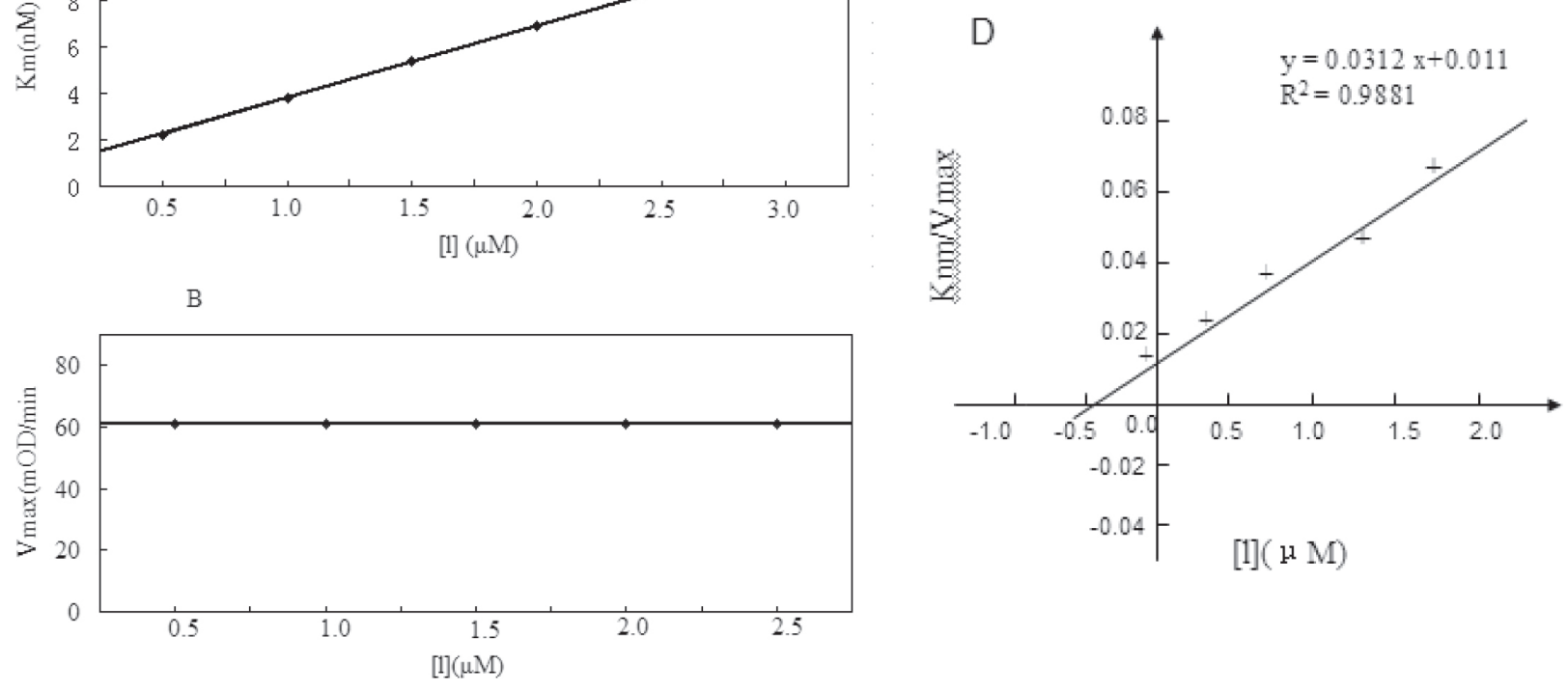

FIGURE 2 - Characterization of the inhibitory mechanism of compound $\mathbf{2 h}$ toward PTP1B. (A) The time-independent inhibition of PTP1B by $\mathbf{2 h}$; (B) At various fixed concentrations of $\mathbf{2 h}$ the initial velocity was determined with various concentrations of $p$ NPP; (C) The mixed inhibition of $\mathbf{2 h}$ shown by Lineweaver-Burk plot; (D) $K_{i}$ determination of $\mathbf{2 h}$

TABLE II - The antitumor activity of compound $\mathbf{2 h}$ in vitro ${ }^{\mathrm{a}}$

\begin{tabular}{lccc}
\hline \multirow{2}{*}{ Compounds } & \multicolumn{3}{c}{$\mathrm{IC}_{50}(\mu \mathrm{g} / \mathrm{mL})$} \\
\cline { 2 - 4 } & $\mathrm{A} 549$ & $\mathrm{HCT} 116$ & $\mathrm{HeLa}$ \\
\hline IRT & $1.65 \pm 0.03$ & $1.43 \pm 0.06$ & $1.62 \pm 0.07$ \\
$\mathbf{2 h}$ & $2.86 \pm 0.09$ & $3.59 \pm 0.07$ & $2.78 \pm 0.11$ \\
\hline
\end{tabular}

${ }^{a}$ Cancer cells: A549: lung cancer; HCT116:colon cancer; HeLa: cervical carcinoma cell.

carcinoma) human tumour xenograft model were evaluated (Figure 3). IRT, a clinical relevant camptothecin, was chosen as a reference drug. The tested compounds were formulated in carboxymethyl cellulose sodium and water were given the orally by gavage. In the colo205 xenograft model, compound $\mathbf{2 h}$ produced a tumor volume inhibition of $\sim 50 \%$ when administered once daily for five consecutive days. However, compound $\mathbf{2 h}$ showed to be well tolerated at a dose of $10 \mathrm{mg} / \mathrm{kg}$ no lethal toxicity occurred.

\section{CONCLUSION}

In summary, 15 2,3-dioxoindolin-1-yl- $N$ phenylacetamide compounds were synthesized and screened for inhibition of CDC25B and PTP1B in vitro. Compound $\mathbf{2 h}$ showed the most inhibitory activity against both CDC25B and PTP1B. Enzyme kinetic experiments demonstrated that compound $\mathbf{2} \mathbf{h}$ was a nonspecific inhibitor with the typical characteristics of a mixed 


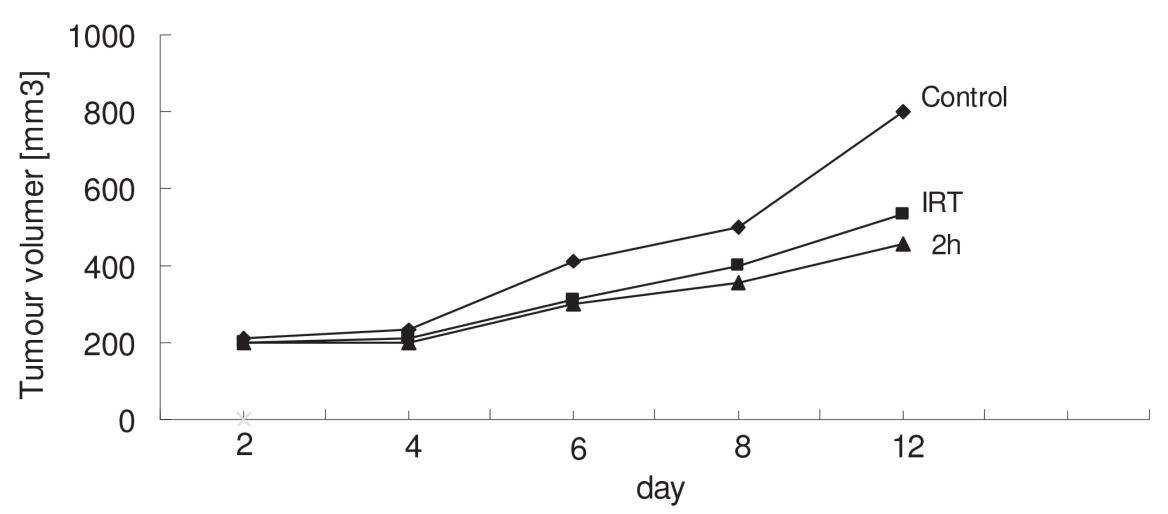

FIGURE 3 - Tumor growth inhibition of colo205 xenografts in nude mice by compound $\mathbf{2 h}$ administered intragastrically.

inhibitor. Cytotoxic activity assays showed compound $\mathbf{2 h}$ is the potent against A549, HeLa and HCT116. In addition, compound $\mathbf{2 h}$ displayed potent tumor inhibitory activity in a colo205 xenograft model. These results indicate that compound $\mathbf{2 h}$ is a promising lead compound for the development of a new group of cancer chemotherapeutics.

\section{ACKNOWLEDGEMENTS}

This work was supported by Zhejiang Province Public Technology Application Project (No. 2017C33131) and the Science and Technology Program Project of Zhoushan City of China (No. 2016C41005). We thank Victoria Muir, PhD, from Liwen Bianji, Edanz Group China (www.liwenbianji.cn/ac), for editing the English text of a draft of this manuscript.

\section{REFERENCES}

Aressy B, Ducommun B. Cell cycle control by the CDC25 phosphatases. Anti-Cancer Agents Med Chem. 2008;8(8):818824.

Barr AJ. Protein tyrosine phosphatases as drug targets: strategies and challenges of inhibitor development. Future Med Chem. 2010;2(10):1563-1576.

Broadbent A, Thomas H, Broadbent S. The chemistry and pharmacology of indole-3- carbinol (indole-3-methanol) and 3-(methoxy methyl)-indole [Part II]. Curr Med Chem. 1998;5(6):469-491.

Contour-Galcera MO, Sidhu A, Prevost G, Bigg D, Ducommun B. What's new on CDC25 phosphatase inhibitors. Pharmacol Ther. 2007;115(1):1-12.
Cossy J, Belotti D, Brisson M, Skoko JJ, Wipf P, Lazo JS. Biological evaluation of newly synthesized quinoline5,8-quinones as Cdc25B inhibitors. Bioorg Med Chem. 2006;14(14):6283-6287.

Eshbha NH, Salama HM. 5-(2-Oxo-3-indolinylidene) thiazolidine-2,4-dione-1,3-dimannich base derivatives: synthesis and evaluation for antileukemic activity. Pharmazie. 1985;40(5):320-322.

Feldhammer M, Uetani N, Miranda-Saavedra D, Tremblay ML. PTP1B: A simple enzyme for a complex world. Crit Rev Biochem Mol Biol. 2013,48(5):430-445.

Julien SG, Dubé N, Read M, Penney J, Paquet M, Han Y, et al. Protein tyrosine phosphatase 1B deficiency or inhibition delays ErbB2- induced mammary tumorigenesis and protects from lung metastasis. Nat Genet. 2007;39(3):338-346.

Lavecchia A, Di Giovanni C, Novellino E. CDC25 phosphatase inhibitors: an update. Mini Rev Med Chem. 2011;12(1):62-73.

Lavecchia A, Coluccia A, Di Giovanni C, Novellino E. Cdc 25B phosphatase inhibitors in cancer therapy: latest developments, trends and medicinal chemistry perspective. Anticancer Agents Med Chem. 2008;8(8):843-856.

Li Y, Yu Y, Jin K, Gao L, Luo T, Sheng L, Shao X, Li J. Synthesis and biological evaluation of novel thiadiazole amides as potent Cdc25B and PTP1B inhibitors. Bioorg Med Chem Lett. 2014;24(17):4125-4128.

Low JL, Chai CLL, Yao SQ. Bidentate inhibitors of protein tyrosine phosphatases. Antioxid Redox Signal. 2014;20(14):2225-2250. 
Malla P, Kumar R, Kumar M. Validation of formylchromane derivatives as protein tyrosine phosphatase $1 \mathrm{~B}$ inhibitors by pharmacophore modeling, atom-based 3D-QSAR and docking studies. Chem Biol Drug Des. 2013;82(1):71-80.

Mak LH, Knott J, Scott KA, Scott C, Whyte GF, Ye Y, et al. Arylstibonic acids are potent and isoform-selective inhibitors of Cdc25a and Cdc25b phosphatases. Bioorg Med Chem. 2012;20(14):4371-4376.

Mcgovern SL, Helfand BT, Feng B, Shoichet BK. A specific mechanism of nonspecific inhibition. J Med Chem. 2003;46(20):4265-4272.

Modi NR, Shah RJ, Patel MJ, Suthar M, Chauhan BF, Patel LJ. Design, synthesis, and QSAR study of novel 2-(2,3-dioxo2,3-dihydro-1H-indol-1-yl)-N-phenylacetamide derivatives as cytotoxic agents. Med Chem Res. 2011;20(5):615-625.

Pandeya SN, Smitha S, Jyoti M, Sridhar SK. Biological activities of isatin and its derivatives. Acta Pharm. 2005;55(1):27-46.

Pandeya SN, Raja AS. Synthesis of istain semicarbazones as novel anticonvulsant-role of hydrogen bonding. J Pharm Pharm Sci. 2002;5(3):266-271.

Reddy MV, Ghadiyaram C, Pamigrah SK, Krishnamurthy NR, Hosahall S, Chandrasekharappa AP, et al. X-ray structure of PTP1B in complex with a new PTP1B inhibitor. Protein Pept Lett. 2014;21(1):90-93.

Rudolph J. Cdc25 phosphatases: structure, specificity, and mechanism. Biochem. 2007;463:595-604.

Shi L, Yu HP, Zhou YY, Du JQ, Shen Q, Li JY, Li J. Discovery of a novel competitive inhibitor of PTP1B by high-throughput screening. Acta Pharmacol Sin. 2008;29(2):278-284.

Sukhramani PS, Desai SA, Suthar MP. In-vitro Cytotoxicity screening of 2-(2, 3-dioxo-2, 3-dihydro-1H-indol-1-yl)-Nphenylacetamide derivatives for anti-lung and anti-breast cancer activity. J Pharm Res. 2011;4(1):124-127.

Sun LP, Ma WP, Gao LX, Yang LL, Quan YC, Li J, Piao HR. Synthesis and characterization of 5,7-dihydroxyflavanone derivatives as novel protein tyrosine phosphatase 1B inhibitors. J Enzyme Inhib Med Chem. 2013a;28(6):1199-1204.
Sun LP, Gao LX, Ma WP, Nan FJ, Li J, Piao HR. Synthesis and biological evaluation of 2,4,6-trihydroxychalcone derivatives as novel protein tyrosine phosphatase 1B inhibitors. Chem Biol Drug Des. 2012b;80(4):584-590.

Teitz Y, Ladizensky E, Barko N, Burstein E. Selective repression of $\mathrm{V}$-alb encoded protein by $\mathrm{N}$-methyl- isatinbeta-4',4'-diethyl thiosemicarbazone and $\mathrm{N}$-allylisatin-beta4',4'-diallylthiosemica-rbazone. Antimicrob Agents Chemother. 1993;37(11):2483-2486.

Tripathi RK, Krishnamurthy S, Ayyannan SR. Discovery of 3-hydroxy-3-phenacyloxi- ndole analogues of isatin as potential monoamine oxidase inhibitors. Chem Med Chem. 2016;11(1):119-32.

Xie C, Tang LM, Li FN, Guan LP, Pan CY, Wang S. Structurebased design, synthesis, and anticonvulsant activity of isatin-1-N-phenylacetamide derivatives. Med Chem Res. 2014a;23(5):2161-2168.

Xie C, Sun Y, Pan CY, Tang LM, Guan LP. 2,4-Dihydroxychalcone derivatives as novel potent cell division cycle $25 \mathrm{~B}$ phosphatase inhibitors and protein tyrosine phosphatase 1B inhibitors. Pharmazie. 2014b;69(4):257-262.

Zarling AL, Obeng RC, Desch AN, Pinczewsli J, Cummings KL, Deacon DH, et al. MHC-restricted phosphopeptides from insulin receptor substrate- 2 and $\mathrm{CDC} 25 \mathrm{~b}$ offer broadbased immunotherapeutic agents for cancer. Cancer Res. 2014:74(23):6784-6795.

Zhao SL, Peng Z, Zhen XH, Han Y, Jiang HY, Qu YL, Guan LP. 6-Bromo- 2,3-diox- oindolin phenylacetamide derivatives: synthesis, potent CDC25B, PTP1B inhibitors and anticancer activity. Lett Drug Des Discov. 2015a;12:529-536.

Zhao SL, Peng Z, Zhen XH, Jin HG, Han Y, Qu YL, Guan LP. Potent CDC25B and PTP1B phosphatase inhibitors: 2',4',6'-trihydroxylchalcone derivatives. Med. Chem. Res. 2015b;24(6):2573-2579.

Received for publication on $13^{\text {th }}$ December 2016 Accepted for publication on $10^{\text {th }}$ July 2018 